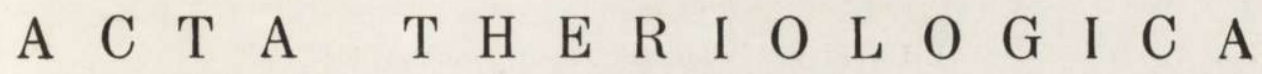

VOL. XII, 15: 245-252.

BIAŁOWIEŻA

30.VII. 1967

\author{
Irena D Z I E R Ż Y R A Y - R O G A L S K A \\ \& Barbara OB U C H OW I C Z
}

\section{The Eifiect of Excision of the Parathyroid Glands on the Morphological Picture of Submandibular Salivary Glands in White Rats}

\author{
[With 1 Table \& Plates VIII, IX]
}

Examination was made of the effect of removal of the parathyroid glands on the morphological picture of the submandibular salivary glands of the white rat. It was found that excision of the parathyroid glands causes morphological changes in the submandibular salivary gland, the most distinct changes being observed from the 7th to 21st day after operation. The changes consisted in obliteration of vesicular structure, reduction in the size of vesicles, reduction in the height of the cells of granular sections, reduction in the dimensions of the cellular nuclei and occurrence of nuclear polymorphism, hypertrophy of connective tissue, enlargement of the lymphatic vessels round the vesicles and ducts. Excision of the parathyroid glands causes a reduction in the calcium level of the blood serum of from $10 \mathrm{mg} \%$ to $7.1 \mathrm{mg} \%$. Four weeks after excision of the parathyroid glands regenerative changes are observed, the characteristic vesicular structure can be distinguished, and mitosis appears within the cells.

\section{INTRODUCTION}

The literature referred to in an earlier study by Dzier żykray - R o ga ls ka (1963) showed that the salivary glands secrete a specific, biologically active substance, which has been termed parotin. It affects tissues of a mesenchymatous origin, is capable of calcifying hard tissues and causing changes in the calcium level in the blood serum [Ito et al. $(1954 ; 1955 ; 1960), \mathrm{Shib}$ a ta et al. (1954), Ogat a (1955), Fujii et al. (1960), $\mathrm{K}$ awa a (1962), G andini et al. (1965)].

As we did not find studies in the literature to which we had access on the connections between submandibular salivary glands and parathyroids, the aim of the present investigations was to trace this process. 


\section{MATERIAL AND METHODS}

Twenty-one young sexually mature male white rats, weighing about $200 \mathrm{~g}$ each, were used for the investigations. The animals were fed on a standard granulated food. The parathyroid glands were excised from thirteen of these rats, while eight animals were used as controls.

The material consisted of the following groups:

Control group A - animals left intact 4 rats

Control group B - animals on which a wblind operation was performed 4 rats

Group 1 - animals killed 2 days after the operation 3 rats

Group 2 - animals killed 7 days after the operation 3 rats

Group 3 - animals killed 14 days after the operation 4 rats

Group 4 - animals killed 28 days after the operation 3 rats

Total 21 rats

The rats which had been deprived of their parathyroid glands were killed at different intervals from the time of the operation. Before the animals were killed blood was taken from them by means of cardiac puncture in order to define the calcium content in the serum. Calcium level was calculated by means of flame photometer (Carl-Zeiss model III), previously drawing the calibration curve for calcium.

The submandibular salivary glands were removed during dissection. One gland (the right one) was fixed in Bouin's fluid, the other in Lison-Vokaer fluid and formol, then saturated in paraffin. Sections 6 microns thick were stained by the following methods: hematoxylin-eosine and the Azan-Mallory method for obtaining preparations for inspection, and the Pas-iron method to discover the presence of mucopolysaccharids, and the Graumann-Claus modification of Müller's method, using colloidal iron to discover acid mucopolysaccharids.

\section{RESULTS}

Control group (controls A and B)

Calcium level - average $10 \mathrm{mg} \%$.

The submandibular salivary gland in white rats is a lobular gland consisting of: 1. final secreting sections (seromucous vesicles, and ducts, occurring very scantily, of a purely mucous character), 2. insertions, 3. granular sections, 4. Pflüger's salivary ducts (Fig. 1). The seromucous vesicles (formerly considered as serous) are formed of 6-7 pyramid-shaped cells with basophilic cytoplasm. The diameters of the vesicles vary within limits of $50 \times 50$ microns. Round cellular nuclei measuring 8-9 microns in diameter are situated in the centre or near the base of the cell. The vesicles give a positive PAS reaction, and stain with colloidal iron. These reactions would indicate that the vesicles are of a seromucous character. The mucous ducts, which occur scantily within the lobe, give an intense PAS reaction, and stain with mucicarmine.

The structure of the insertions does not differ from descriptions given in textbooks.

The granular sections lie between the insertion and Pflüger's salivary 
duct. They are tubular in form, often branching with clearly visible lumen. They are formed of high cells (29.5-29.9 microns). The cellular nuclei measuring $7.9-8.3$ in diameter are situated nearer the base. Granular matter staining with ferrous hematoxylin and azocarmine are observed in the apical parts of the cytoplasm of the granular sections. This granular matter is particularly distinct after using certain fixing fluids such as, for instance, formol. The granular sections were formerly termed mucous ducts, but the cells of these sections do not give the reactions characteristic of mucous cells, as stated by $\mathrm{Schmidt}$ (1955), S i uda (1961), Flores - Veas (1964), G a ndin i et al. (1965). Pflüger's salivary ducts are collector ducts lined with cylindrical epithelium.

Table 1.

Diameter of vesicles, nuclei of vesicular cells and heights of cells and nuclei of granular sections.

\begin{tabular}{|l|c|c|c|c|}
\hline $\begin{array}{c}\text { Experimental } \\
\text { groups }\end{array}$ & $\begin{array}{c}\text { Diameters } \\
\text { of vesicles } \\
\text { in } \mu\end{array}$ & $\begin{array}{c}\text { Diameters of } \\
\text { nuclei" of vesicular } \\
\text { cells in } \mu\end{array}$ & $\begin{array}{c}\text { Height of cells } \\
\text { of granular } \\
\text { sections in } \mu\end{array}$ & $\begin{array}{c}\text { Diameters of } \\
\text { cellular nuclei } \\
\text { of granular } \\
\text { sections in } \mu\end{array}$ \\
\hline Control I & $50 \times 50$ & $9.0 \times 9.0$ & 29.5 & $8.3 \times 8.3$ \\
Control II & $52 \times 55$ & $8.0 \times 8.0$ & 29.9 & $7.9 \times 7.9$ \\
Group 1 & $38 \times 38$ & $8.0 \times 80$ & 27.0 & $5.8 \times 5.8$ \\
Group 2 & $40 \times 40$ & $5.0 \times 7.0$ & 27.2 & $5.1 \times 5.1$ \\
Group 3 & $40 \times 40$ & $7.0 \times 7.0$ & 28.0 & $7.0 \times 7.0$ \\
Group 4 & $50 \times 50$ & $8.0 \times 8.0$ & 28.0 & $7.0 \times 7.0$ \\
\hline
\end{tabular}

The round cellular nuclei lie in the centre or nearer the lumen of the duct. The cytoplasm of the cells stain with acid staining agents. Characteristic striation is also observed in the basal parts of the cells. No differences were found in the structure of the salivary glands between control groups A and B (Fig. 2).

\section{Group 1.}

Animals killed two days after excision of their parathyroid glands. Mean calcium level $7.1 \mathrm{mg} \%$.

Bands of connective tissue are observed to penetrate into the glandular parenchyma in the salivary glands of this group of animals. This causes characteristic obliteration of the vesicular structure. The size of the vesicles decreases (diameters of the vesicles $38 \times 38$ microns). Simultaneously changes are observed to take place within the cellular nuclei, both in the vesicles and the granular sections. The nuclei described become hyperchromatic. The nuclear membrane is rugose, 
making the shape irregular. The nuclei are unevenly distributed as a result of obliteration of the vesicular structure (Fig. 3). Granular sections give a PAS + reaction, but it is weaker than that observed in the control animals.

Group 2.

Animals killed 7 days after excision of their parathyroid glands. Mean calcium level $7.1 \mathrm{mg} \%$.

Progressive obliteration of vesicular structure is observed in the salivary glands of this group of animals. The amount of connective tissue and blood vessels increases between the final sections and round the Pflüger's ducts, and enlarged lymphatic vessels appear. The diameter of the final sections which still retained their vesicular structure vary within limits of $40 \times 40$ microns. Nuclear polymorphism is found to occur in the vesicles. Some of them-are hyperchromatic with rugose nuclear membrane, others, also hyperchromatic, are elongated with diameters of $5.0 \times 7.0$ microns. In addition nuclei with a distinct chromatin stroma are observed. The cellular nuclei become distinctly smaller $(5.1 \times 5.1$ microns) (Fig. 4). A secretion giving a PAS + reaction is found both in the cells and in the lumen of granular sections.

\section{Group 3.}

Animals killed 14 days after excision of their parathyroid glands. Mean calcium level $7.5 \mathrm{mg} \%$.

Intensification of the process described in group 2 is observed in the salivary glands of this group of animals. Obliteration of the vesicular structure progresses in certain parts of the lobes. It is difficult to distinguish the limits of the different vesicles (Fig. 5). At the same time the number of enlarged lymphatic vessels surrounding the vesicles and ducts increases. The cellular nuclei still exhibit polymorphism (Fig. 6). Histochemical tests take the same course as in group 2 .

\section{Group 4.}

- Animals killed 28 days after excision of their parathyroid glands. Mean calcium level $8.1 \mathrm{mg} \%$.

Changes take place in the salivary glands of this group of animals which might form evidence of the regeneration of the gland. An increasingly large number of normally built lobes can be observed, but the lymphatic vessels continue to be very enlarged. Dimensions of the vesicles increase ( $50 \times 50$ microns), as does the height of the cells of the granular sections (28 microns). An increasingly large number of nuclei 
in the vesicular cells exhibit a distinct chromatin stroma with a clearly visible nucleole (Fig.7). Mitosis is found both in the cells of the vesicles and of the granular sections (Fig. 8).

\section{DISCUSSION}

Despite the fact that there is a very large number of studies dealing with the changes taking place in the salivary glands after removal of different endocrine glands, we found no discussion in the literature available of the changes taking place in submandibular salivary glands as the result of excision of the parathyroid glands. The investigations made show that lack of the latter glands causes considerable morphological changes in the submandibular salivary glands of the white rat, the changes chiefly affecting the final vesicular sections. The granular sections also undergo changes but they are not so distinctly marked. Changes in the vesicles consist in: obliteration of the characteristic structure, reduction in size of the vesicles, reduction in size of cells and nuclei and appearance of nuclear polymorphism. The above changes may form evidence of the decreased activity of the submandibular salivary glands. The appearance of enlarged lymphatic vessels as early as the first week after removal of the parathyroids is, however, difficult to interpret.

O g a t a (1955) in evoking hypofunction of the salivary glands in rats, also obtained hypofunction of the parathyroids. Gabe (1950) who examined the submandibular salivary gland in white mice in which rickets had been induced, found atrophy of the final and granular sections.

Dzierżykray-Rogalska (1963) obtained morphological pictures indicating hypofunction of the parotid salivary glands by excising parathyroids from white rats. Interpretation of the results obtained is attended with some difficulty, and it is not possible to draw any far-reaching conclusions on the basis of the studies made. Changes were observed in the salivary glands which probably led to reconstruction of the gland. It is difficult to consider the simultaneous occurrence of enlarged lymphatic vessels as an indicator of the glands' inhibited functions. Twenty-eight days after the operation the gland was observed to have returned to normal.

\section{REFERENCES}

1. Attardi D. G., Levi-Montalcini R., Wagner B. S. \& Angeletti P. U., 1965: Submaxillary gland of mouse: Effect of a fraction on tissues of mesodermal origine in vitro. Science 150, 3701: 1307-1309. 
2. Dzierżykay-Rogalska I., 1963: The connection between the endocrine activity of the parotid salivary glands and parathyroid on the morphological pictures. Acta theriol., 7, 12: 215-258.

3. Dzierżykray-Rogalska I., Chodynicki S. \& Wiśniewski L., 1960: Wpływ usunięcia jąder na śliniankę przyuszną i gruczoł Loeventhala myszy białej. Endokr. pol., 11: 105-116.

4. Dzierżykray-Rogalska I. \& Gutsze L., 1963: Untersuchungen über das Einwirken von Parotin und über die Wirkung der Entfernung der Ohrspeicheldrüse auf das autoradiographische Bild bei weissen Ratten. Ztschr. mikr. anat. Forsch., 70, 4: 465-470.

5. Dzierżykray-Rogalska I. \& Serwatko A., 1964: The effect of reduced calcium level in blood serum on the morphological picture of the adrenal glands of the white rat. Acta theriol., 8, 15: 227-236.

6. Dzierźykray-Rogalska I. \& Wenderlich K., 1965: Effect of administration of parotin and excision of parotid salivary glands on the morphological picture of islets of Langerhans in the pancreas of the white rat. Acta theriol., 10, 20: 289-296.

7. Flores-Veas G., 1964: Contribucion al etude de la glaude salivarie des Rongeurs. Etude histologique et expèrimentale chez la Rat albinos. Ztschr. mikr. anat. Forsch., 71, 3:

8. Fujii A., Komura M. \& Yang M. F., 1960: The effects of adrenalectomy and cortisone upon the glycogen contens in various organs especially in the parathyroid gland of the rat. Acta Scholae Med. in Gifu, 8: 600-612.

9. G a be M. M., 1950: Action du rachsime sur le glande sous-maxillaire de la souris albinos. C. R. Acad. Sc., 230: 72-74.

10. It o Y., 1954: Biochemical studies on salivary gland hormone. Endocr. jap., 1: 1 - 50 ,

11. It o Y. \& Okabe S., 1955: On the occurrence of a parotin-like substance (saliva-parotin) in the human saliva. Endocr. jap., 2: 195.

12. I to Y., 1960: Parotin a salivary gland hormone. Ann. New York Acad. Sc., 85: $228-310$.

13. K a w a d a J., 1962: On the functional correlation between salivary glands and other endocrine organs. V - Changes in rat salivary glands following thyroidectomy, administration of anti-thyroid drugs and thyroxine-treament. Endocr. jap., 8: 259-271.

14. Ogata T., 1955: The internal secretion of salivary gland. Endocr. jap., 11: $1-15$.

15. Parhon C. I., Babes A. \& Petrea I., 1957: Endocrinologia glandelor salivare. Biblioteca Medicale, 5: 1-200. Editura Academiei R. P. R.

16. Parhon C. I., B a bes A., Petrea I. \& Istrati F., 1955: Asupra structurii glandelor parotide de sobolan in raport ou virsta si momentul aparitiei dimorfismului sexual. Comunicare Academiei R. P. R., 5, 12: 1-310.

17. Parhon C. I., Petrea I. \& Saposnie A., 1956: Asupra actiunii hiperglicemiante a und extract de parotida. Studii si cercetari de Endocr., 7: 2.

18. Schmidt E. S. G., 1959: Der Einfluss des Winterschlafes, des Megaphenschlafes, des Hungerns and verschiedener Kastraten auf die Speicheldrüsen von Myoxus, Erinaceus europaeus, Mus und Rattus. Ztschr. Zellf. Mikr. Anat., 50: $143-182$. 
19. Sh ibat a K., Negis hi A., S a it o K. \& T a d or o S., 1954: Effect of salivary glandectcmy on the response of the epiphysis to growth hormone. Endocr. jap., 1: 203-207.

20. S i u da S. \& S z y ma ń s k a Z., 1961: Comparative investigations of the salivary glands of small rodents. Acta theriol., 5, 11: 141-151.

Received, October 15, 1966.

Academy of Physical Education, Department of Biology,

Medical Academy,

Warszawa, Marymoncka 34 .

and

Dept. of Histology and Embryology, Białystok, Kilińskiego 1.

\section{Irena DZIERŻYKRAY-ROGALSKA \& Barbara OBUCHOWICZ}

\section{WPŁYW WYCIĘCIA PRZYTARCZYC NA OBRAZ MORFOLOGICZNY SLINIANKI PODŻUCHWOWEJ U SZCZURA BIAEEGO}

\section{Streszczenie}

Badano wpływ jaki wywiera usunięcie przytarczyc na obraz morfologiczny ślinianki podżuchwowej szczura białego. Stwierdzono, że wycięcie przytarczyc powoduje zmiany morfologiczne w obrębie ślinianki podżuchwowej. Najbardziej zaznaczone zmiany obserwuje się od 7-go do 21-go dnia po zabiegu. Obserwowane zmiany dotyczą zatarcia budowy pęcherzykowej, zmniejszenia wielkości pęcherzyków, zmniejszenia wysokości komórek odcinków ziarnistych, zmniejszenia wymiarów jąder komórkowych i występowania polimorfizmu jądrowego, rozrostu tkanki łącznej, rozszerzenia naczyń limfatycznych dookoła pęcherzyków i cewek (Tabela 1, Fig. 1-8). Wycięcie przytarczyc powoduje obniżenie poziomu wapnia w surowicy krwi z $10 \mathrm{mg} \%$ na $7,1 \mathrm{mg}^{\circ}$. W 4 tygodnie po wycięciu przytarczyc obserwuje się zmiany regeneracyjne, zaznacza się charakterystyczna budowa pęcherzykowa, w obrębie komórek pojawiają się mitozy. 


\section{PLATE VIII.}

Fig. 1. Diagram of the structure of the submandibular salivary gland in the white rat.

A - final secretory mucoserous sections, B - insertion, C - granular section, , D - Pflüger's salivary duct.

Fig. 2. Submandibular salivary gland of control rat. Final secretory mucoserousus sections (magnified $560 \times$ ).

Fig. 3. Submandibular salivary gland of a rat killed 2 days affer excision of pararathyroid glands. Final secretory mucoserous sections. Obliterated vesicular structurure (magnified $560 \times)$.

Fig. 4. Submandibular salivary gland of a rat killed 7 days after excision of pararathyroid glands. Final secretory mucoserous sections and granular section. Disturbebed vesicular structure. Enlarged lymphatic vessels. Polymorphism of cellular nuclclei (magnified $560 \times$ ).

\section{PLATE IX.}

Fig. 5. Submandibular salivary gland of a rat killed 14 days after excision of the parathyroid glands. Final secretory mucoserous sections. It is difficult to distinguisiish single vesicles (magnified $560 \times$ ).

Fig. 6. Submandibular salivary gland of a rat killed 14 days after excision of the parathyroid glands. Final secretory mucoserous sections and granular sectiotion. Penetration of connective tissue and enlarged lymphatic vessels (magnified $560 \times 0 \times$ ).

Fig. 7. Submandibular salivary gland of a rat killed 28 days after excision of pararathyroid glands. Final secretory mucoserous sections, granular section and Pflügüger salivary duct. Distinct and regular vesicles can be seen near the obliterateated vesicular structure. Enlarged lymphatic vessels (magnified $560 \times$ ).

Fig. 8. Submandibular salivary gland of a rat killed 28 days after excision of pariarathyroid glands. Mitosis within vesicular cell (magnified $2800 \times$ ). 


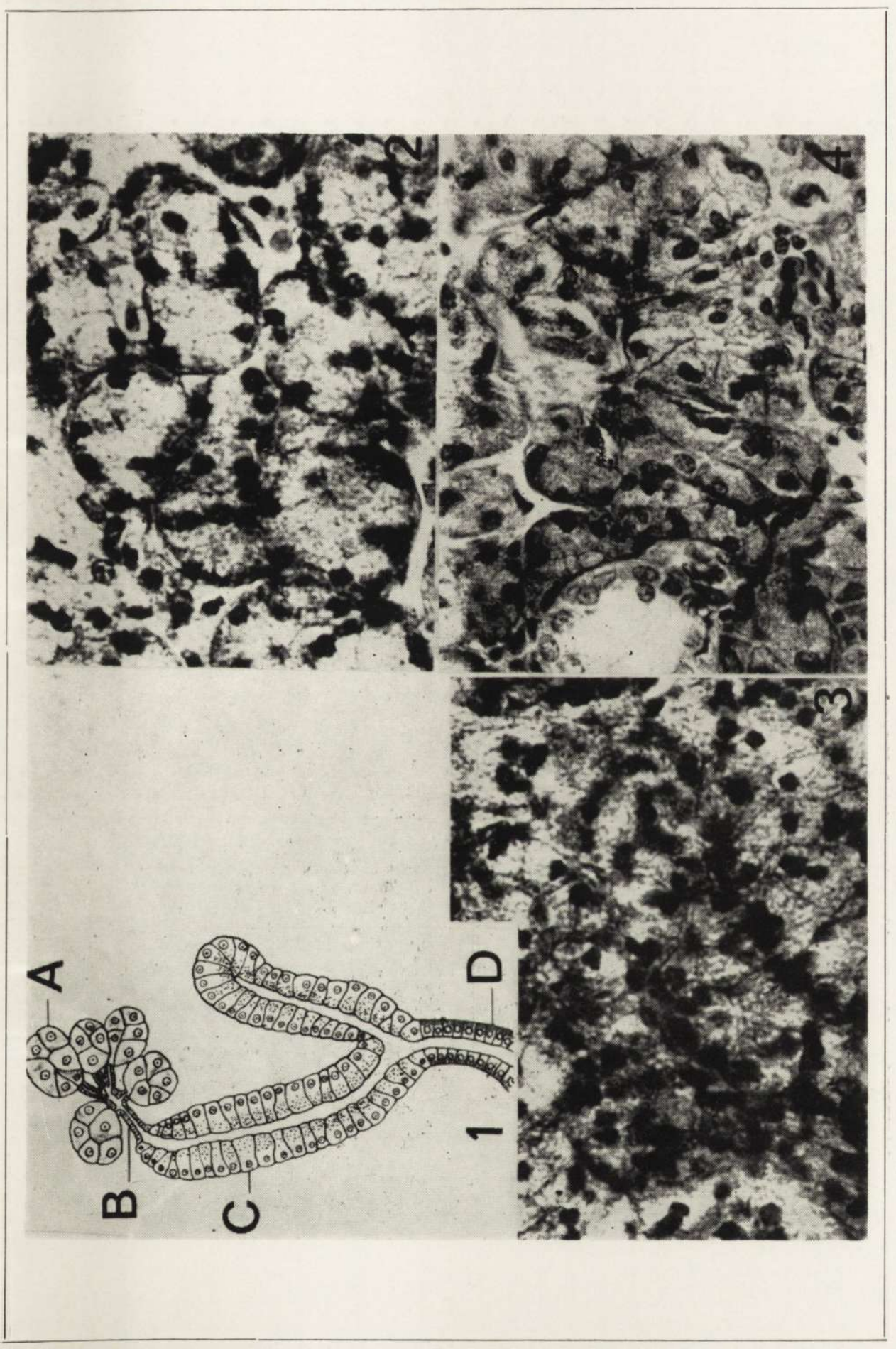

I. Dzierżykray-Rogalska \& B. Obuchowicz auctores phot. 


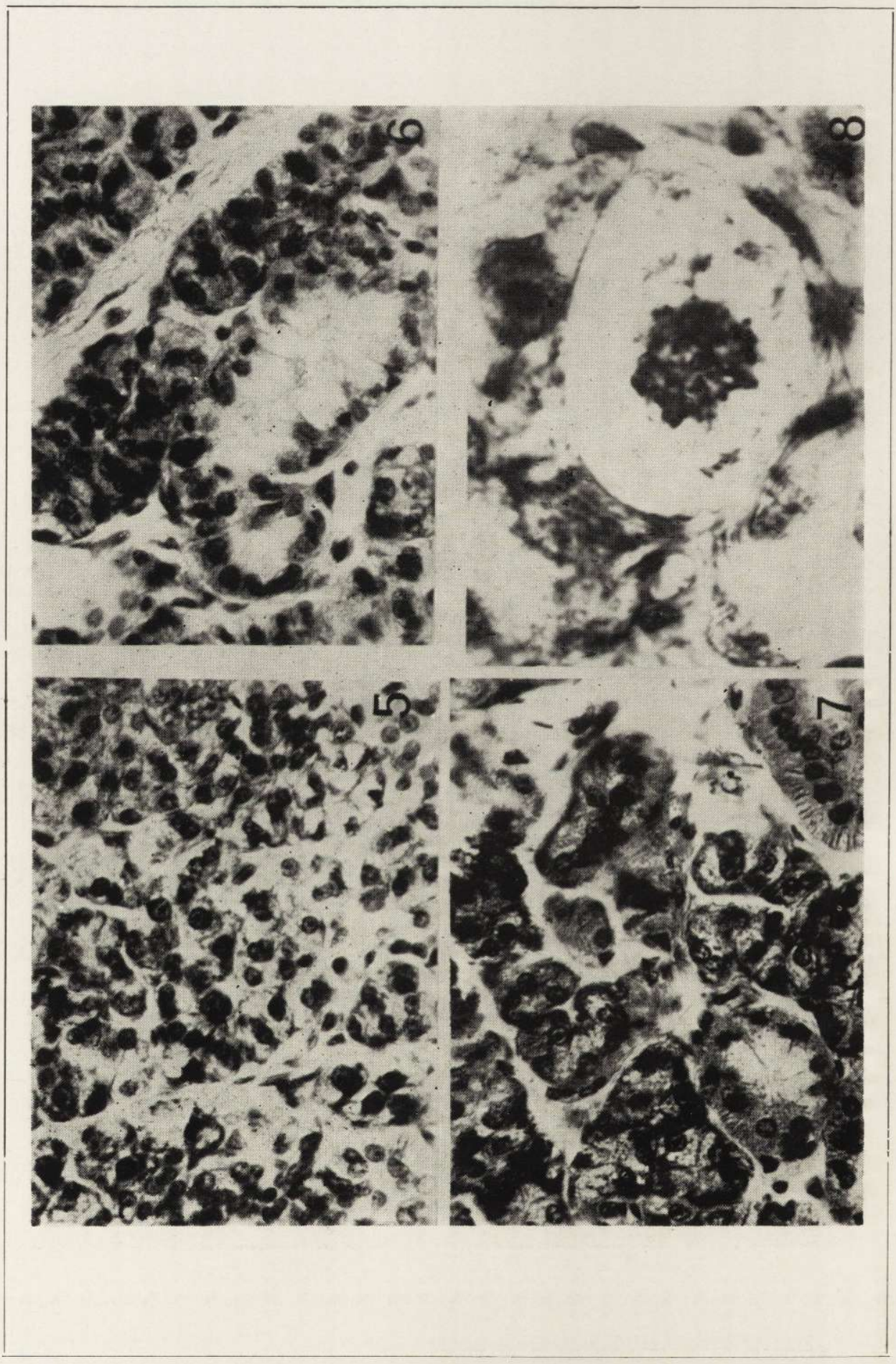

I. Dzierżykray-Rogalska \& B. Obuchowicz

auctores phot. 